\title{
AN EVALUATION OF PATIENTS DIAGNOSED WITH OPTIC NEURITIS IN CHILDHOOD
}

\section{ÇOCUKLUK ÇAĞINDAKI OPTIK NÖRIT TANILI HASTALARIN DEĞERLENDIRILMESI}

\author{
Mahmut ASLAN ${ }^{1}$ (D), Serkan KIRIK ${ }^{1}$ iD, Serdal GÜNGÖR ${ }^{1}$ (D) \\ ${ }^{1}$ Inonu University, Faculty of Medicine, Department of Pediatrics, Division of Pediatric Neurology, Malatya, Turkey
}

ORCID IDs of the authors: M.A. 0000-0002-5355-8994; S.K. 0000-0002-8658-2448; S.G. 0000-0003-3875-6770

Cite this article as: Aslan M, Kirik S, Gungor S. An evaluation of patients diagnosed with optic neuritis in childhood. J Ist Faculty Med 2021;84(3):324-30. doi: 10.26650/IUITFD.2021.814576

\section{ABSTRACT}

Objective: Optic neuritis (ON) is an autoimmune disease that starts with acute and subacute vision loss and is characterized by the demyelination of the optic nerve. It may appear as an isolated, idiopathic condition, or it may be a precursor of diseases such as Multiple Sclerosis (MS) or Neuromyelitis Optica (NMO). In the study, we aimed to evaluate $\mathrm{ON}$ patients and the longterm prognosis in pediatric patients.

Material and Method: In this study, 13 patients who applied to the pediatric neurology clinic between years 2010-2017 and were diagnosed with acute $\mathrm{ON}$ were assessed retrospectively.

Results: Thirteen patients diagnosed with $O N$ were included in our study, six of whom were diagnosed with isolated ON (6/13, $46.15 \%)$. Nine of them were female. The average age of our patients was $12.8 \pm 3.07$ years. Seven patients $(53.85 \%)$ had unilateral involvement. A complete recovery was provided in 12 patients. There were recurrences in the follow-up of two patients, diagnosed with MS.

Conclusion: ON should absolutely be considered in every child with blurred vision and vision loss. Early stage steroid treatment is the most efficient therapy.

Keywords: Demyelinating disease, optic neuritis, pediatric

\section{ÖZET}

Amaç: Optik nörit (ON), akut ve subakut görme kaybı ile başlayan, optik sinirin demiyelinizasyonu ile karakterize bir otoimmün hastalıktır. İzole, idiyopatik bir durum olarak ortaya çıkabildiği gibi Multipl Skleroz (MS) veya Nöromiyelitis Optika (NMO) gibi hastalıkların öncüsü de olabilir. Çalışmamızda çocuk hastalarda optik nörit tanılı vakaların demografik özelliklerini ve uzun dönem prognozu değerlendirmeyi amaçladık.

Gereç ve Yöntem: Bu çalışmada, 2010-2017 yılları arasında çocuk nöroloji kliniğine başvuran ve akut ON tanısı alan hastalar retrospektif olarak değerlendirildi.

Bulgular: $\mathrm{ON}$ tanısı alan 13 hasta çalışmaya dahil edildi. Bunların 6'sına $(\% 46,15)$ izole ON tanısı kondu. Hastaların dokuzu kadın ve ortalama yaş $12,8 \pm 3,07$ yıldı. Yedi hastada $(\% 53,85)$ tek taraflı tutulum vardı. On iki hastada tam bir iyileşme sağlanırken, MS tanısı alan iki hastanın takibinde nüks gelişti.

Sonuç: Görme bulanıklığı ve görme kaybı olan her çocukta ON mutlaka düşünülmelidir. Erken dönem steroid tedavisi en etkili tedavidir.

Anahtar Kelimeler: Demiyelinizan hastalık, optik nörit, pediatrik

\section{INTRODUCTION}

Optic neuritis $(\mathrm{ON})$ is an autoimmune disease that is characterized by the demyelination of the optic nerve. It constitutes $25 \%$ of acute demyelinating syndromes in children. It may either appear as an isolated, idiopathic condition, or it may be a precursor of diseases such as multiple sclerosis (MS) or neuromyelitis optica (NMO). MS has been reported in 38\% of patients who have applied with isolated $\mathrm{ON}(1,2)$. This ratio can go up to $80 \%$ in patients with white matter hyperintensities in cranial Magnetic Resonance Imaging (MRI) (3). The prevalence of $\mathrm{ON}$ was determined as 0.2 in 100,000 in a study performed in Canada (4).

Corresponding author/iletişim kurulacak yazar: srknkrk@hotmail.com

Submitted/Başvuru: 22.10.2020 • Revision Requested/Revizyon Talebi: 02.01.2021 •

Last Revision Received/Son Revizyon: 17.03.2021 • Accepted/Kabul: 18.03.2021 • Published Online/Online Yayın: 12.07.2021 
$\mathrm{ON}$ is characterized by acute and subacute vision loss (4). The cardinal features of $\mathrm{ON}$ include decreased visual acuity, abnormal color vision, and visual field deficits. Visual loss usually occurs over hours to days $(4,5)$. In children, visual acuity at baseline is typically worse than adults, and the possibility of bilateral vision loss is higher. Papillitis is observed more frequently in pediatric patients with optic neuritis, after excluding other possible etiologies resulting in optic disc edema. Optic disc and nerve involvement may be confirmed by visual evoked potential (VEP) $(1,4,5)$. For the differential diagnosis of other diseases that may lead to optic disc edema, neuroimaging, lumbar puncture, and cerebrospinal fluid (CSF) examinations are required (5). In neuroimaging studies, typical MRI findings in dedicated orbital and brain MRI studies consist of the thickening of the optic nerves on T1-weighted imaging, a bright T2 signal along the optic nerve, and post-gadolinium enhancement, all of which are important for a diagnosis (5-7).

Although steroids are the most effective medication in the treatment of acute $\mathrm{ON}$, the forms of use are always controversial. In a multi-center study performed by $O N$ study protocol, the use of steroids through oral, retrobulbar, and intravenous routes were compared. Although intravenous administration of steroids shows a faster effect in previous studies, no differences were determined at the end of one year with regard to vision $(2,6,7)$.

In our study, patients diagnosed with acute $\mathrm{ON}$ were assessed retrospectively. Demographic characteristics, diagnoses, clinical findings, treatment response, and the clinical monitoring of patients were examined. We aimed to evaluate the clinical features and long term prognosis of $\mathrm{ON}$ in pediatric patients.

\section{MATERIAL AND METHODS}

The patients who applied to the pediatric neurology clinic between 2010 and 2017 and were diagnosed with ON were included to our study. ON was diagnosed when patients presented acute or subacute vision loss, decreased visual acuity, papilledema, abnormal color vision, and visual field deficits. Cranial and orbital MRI studies were done in all of the patients. Typical findings indicating $\mathrm{ON}$, which were the thickening of the optic nerves on T1-weighted imaging, bright T2 signal along the optic nerve, and post-gadolinium enhancement, were also noted. This retrospective study was carried out in a tertiary center by evaluating electronic patient files. A lumbar puncture was performed to all the patients. The CSF IgG index was calculated with the CSF IgG index = (CSF IgGxserum albumin)/(CSF albuminxserum IgG) formula. The oligoclonal band (OCB) results were also attained. The demographic characteristics, clinical findings, treatment response, and prognosis of these patients were examined. The patients were followed for 1-4 years. In addition to an MRI, visual and neurological examinations and VEP tests were performed in all patients. VEP tests were considered abnormal when prolonged P100 latencies were present (>114 ms). Patients whose medical records could not be accessed or who were found to have a secondary cause of acute vision loss (orbital mass, intracranial mass-occupying lesion, etc.) were excluded. Besides the patient who was diagnosed with neurobrucellosis, steroid treatment was given immediately to all of the other patients at the acute phase when the diagnosis of optic neuritis was confirmed. The complete recovery of vision loss was assessed as a complete response.

The isolated recurrent $\mathrm{ON}$ was diagnosed in patients having multiple episodes of $\mathrm{ON}$ ( $\geq 2$ episodes) and normal cranial MRI with or without OCBs in CSF (7). For the diagnosis of MS (adults and pediatric patients) the 2017 revised McDonald criteria were used; however, these criteria are sometimes not fulfilled in pediatric patients. If the MRI is normal, the OCB is more important in such cases. A NMO disease was diagnosed when the aquaporin-4 antibody was positive and at least one of the core clinical characteristics was present: 1. Optic neuritis, 2. Acute myelitis, 3. Area postrema syndrome-nausea/vomiting/ hiccups, 4. Other brainstem syndrome, 5. Symptomatic narcolepsy or acute diencephalic syndrome with MRI lesion(s), 6. Symptomatic cerebral syndrome with MRI lesion(s). Specific MRI criteria are not required to confirm a diagnosis of $\mathrm{NMO}(7)$.

\section{RESULTS}

Thirteen patients diagnosed with $\mathrm{ON}$ were included in our study. Among these patients, 5 (38.4\%) had an isolated non-recurrent $\mathrm{ON}$ episode, 5 (38.4\%) were diagnosed with MS, and two patients (15.38\%) were diagnosed with $\mathrm{NMO}$ after the initial work-up. The remaining patient (7.7\%) with neurobrucellosis (Table 1).

The age of our patients ranged between 10-17 years, and the mean age was $15.25 \pm 2.12$ years (Table 1$)$. Nine pa-

Table 1: Patients' demographic findings and diagnosis

\begin{tabular}{lc}
\hline Patient & $\mathbf{n}(\%)$ \\
Age (median) & $12.8 \pm 3.07$ years \\
Gender & \\
$\quad$ Female & $9(69.2)$ \\
$\quad$ Male & $4(30.8)$ \\
Unilateral & $7(53.85)$ \\
Bilateral & $6(46.15)$ \\
Diagnosis & \\
$\quad$ Isolated optic neuritis & $5(38.4)$ \\
$\quad$ Multiple sclerosis & $5(38.4)$ \\
$\quad$ Neuromyelitis optica & $2(15.38)$ \\
$\quad$ Neurobrusellosis & $1(7.7)$ \\
\hline
\end{tabular}




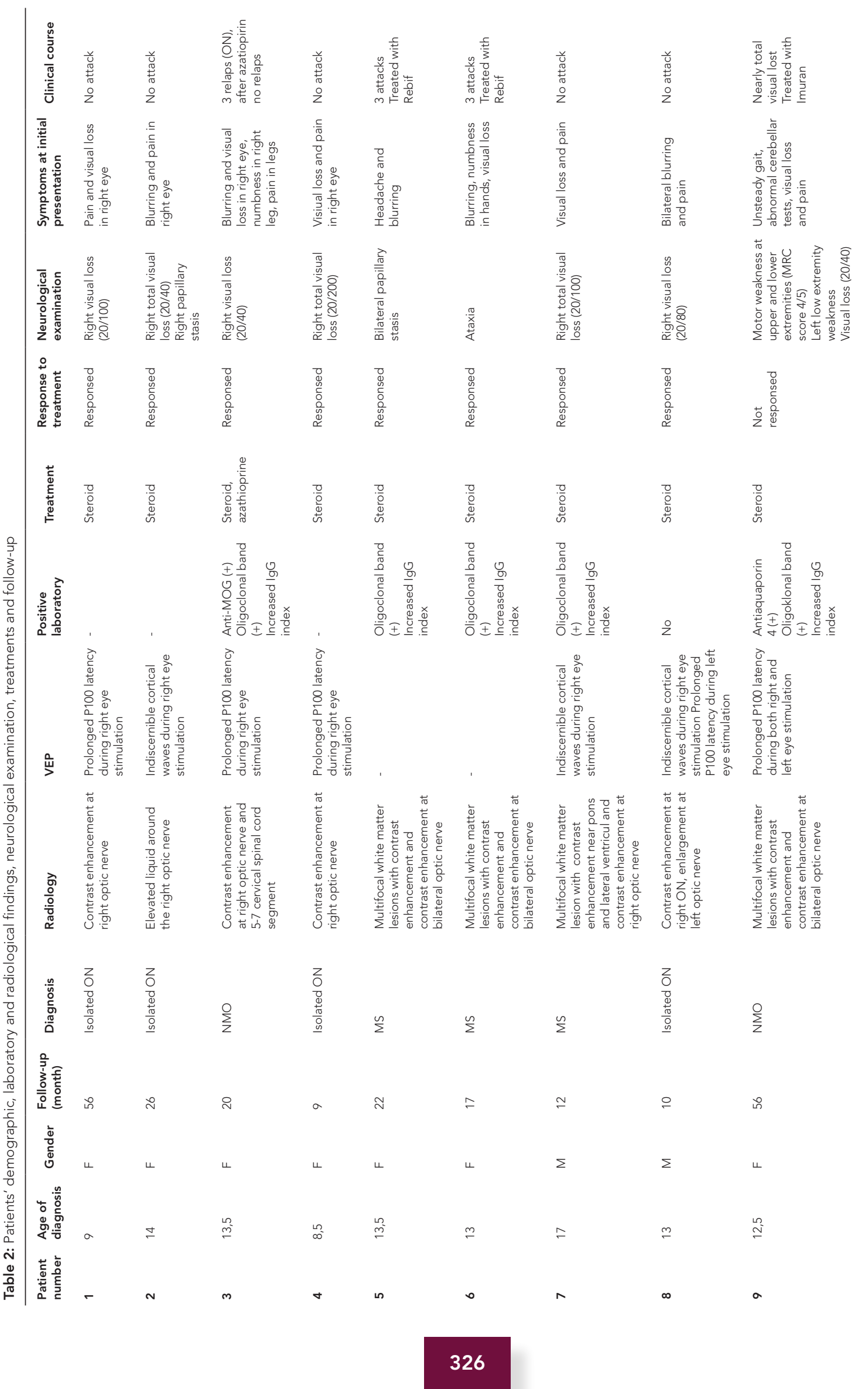




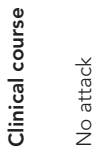

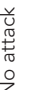
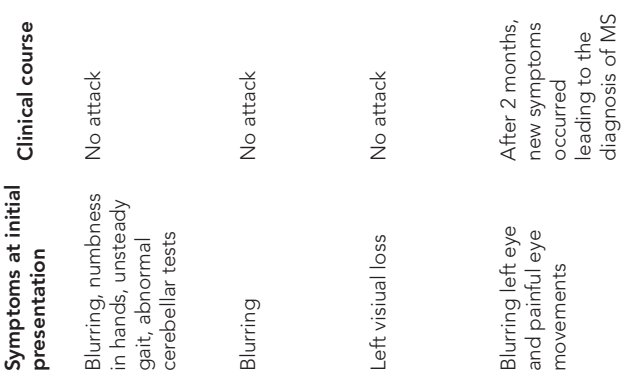

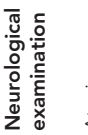

$\underset{\substack{\frac{\pi}{x} \\ \frac{\pi}{4}}}{\frac{\pi}{4}}$

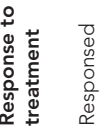

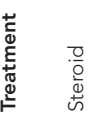

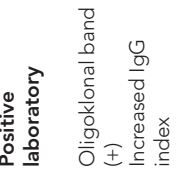

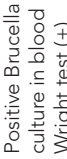
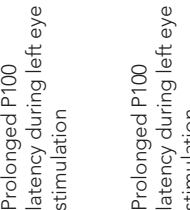

这

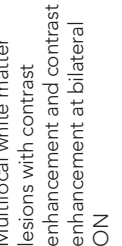

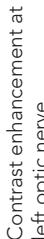

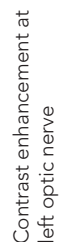

2
0
0
0
0
$\frac{0}{0}$
$\underline{0}$

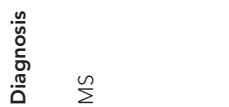

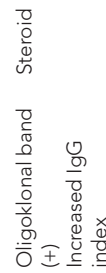
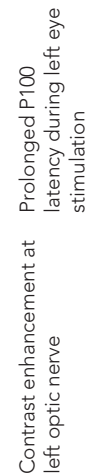

$4 \stackrel{\frac{n}{\omega}}{\circ}$

ฮั ฐ

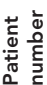

우

$\approx$

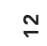

$\stackrel{m}{\sim}$

tients (69.20\%) were female, and 4 patients (30.80\%) were male. The F/M ratio was 2.25. Their ages of diagnosis ranged between 8.5-17 years, with a mean of 12.8+/-3.07 years.

All patients had visual problems such as blurred vision and visual loss as an initial presentation. Five patients diagnosed with isolated $\mathrm{ON}$, one with neurobrucellosis and two with $\mathrm{NMO}$ had unilateral involvement of the optic nerve. Other patients applied with bilateral vision problems. Patients diagnosed with isolated $\mathrm{ON}$ had no additional complaints. Eight patients (61.54\%) had painful eye movements. Eight patients $(61.5 \%)$ had unilateral involvement, and six patients (38.4\%) had bilateral involvement (Table 2).

In the neurological examination of our patients; various levels of vision loss or blurred vision were always present. In the patients whose final diagnoses were MS and $\mathrm{NMO}$, the symptoms and signs in addition to the loss of vision at the initial visit were numbing of the hands, ataxic gait, dysmetria/dysdiadochokinesia, foot drop, and muscle weakness in the lower extremities. Papillary stasis was present in the examination of fundus oculi in three patients who were diagnosed with $M S$, isolated $O N$, and neurobrucellosis. Furthermore, the neurobrucellosis patient had a visual field defect (Table 2).

In all patients diagnosed with MS, there were diffuse plaques with contrast enhancement in the white matter (Figure 1). The cranial MRI of the other patients revealed hypertrophy in the involved optic nerves and contrast enhancement as well (Figure 2). Ten (76.92\%) of the 13 pa-

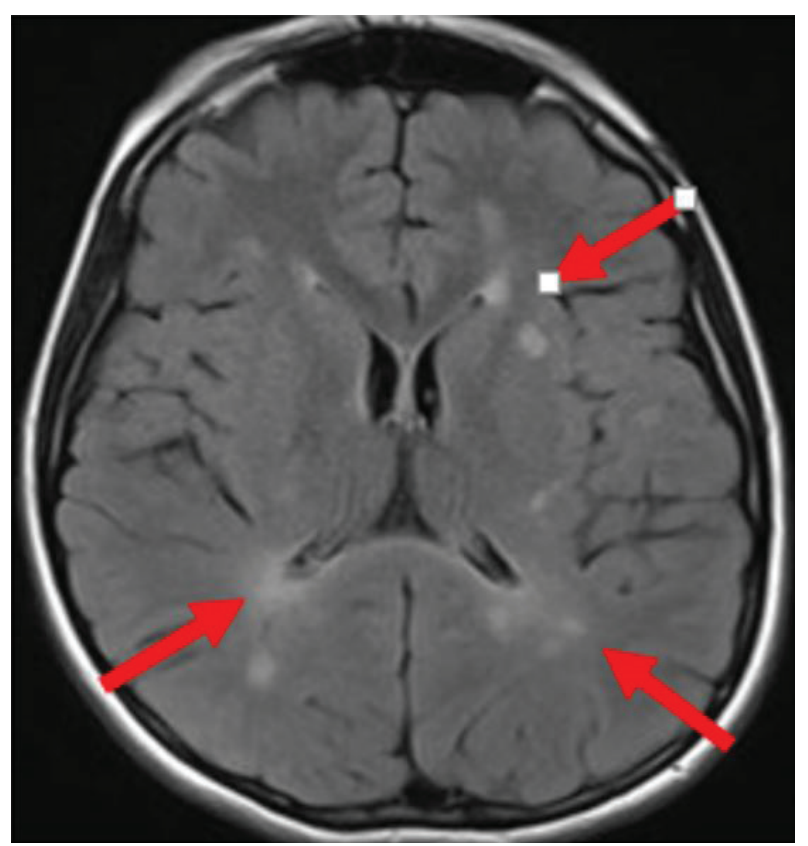

Figure 1: Periventricular and subcortical white matter hyperintensities in T2W images are shown by red arrows (patient 5 in Table 2) 
tients had abnormal VEP tests, the prolonged latencies of P100 wave, or indiscernible cortical waves during the stimulation of the affected eye.

In the CSF examination, glucose levels were normal in all patients, and an elevated cell count was obtained in only

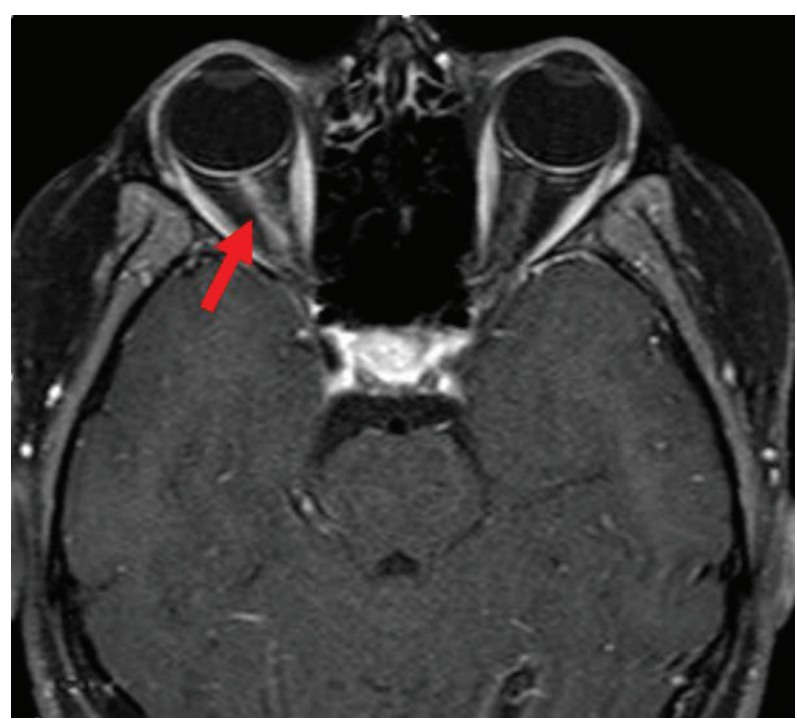

Figure 2: The contrast enhancement due to neuritis in right optic nerve is shown by red arrow (patient 8 in Table 2)

one patient, the one who was diagnosed with neurobrucellosis. In this patient, a lumbar puncture showed pleocytosis of the cerebrospinal fluid, predominantly lymphocytes. This patient also had a Brucella serum agglutination titer of 1/320. An elevated protein level was found in eight patients. The OCB checked in CSF was positive, and the IgG index was increased in all of our patients diagnosed with MS and the patients diagnosed with NMO. Our patient diagnosed with $\mathrm{NMO}$ also had antiaquaporin 4 positivity. There was brucella proliferation in both the blood and CSF culture in our patient diagnosed with neurobrucellosis. There was bilateral optic nerve involvement in three (75\%) of the five patients diagnosed with MS (Table 2). In isolated $\mathrm{ON}$ cases, the initial OCB and IgG index were negative, and no recurrence was found to be an important finding.

All patients were hospitalized, and except for the one with neurobrucellosis, pulse steroids (30 mg/ $\mathrm{kg} /$ day) were administered for five days. In the follow-up, steroids were administered via oral route at $2 \mathrm{mg} / \mathrm{kg} /$ day dose, and they were stopped after decreasing the dose for 4-6 weeks. One of our NMO patients did not responded to treatment. The patient who was diagnosed with NMO developed permanent visual loss because he applied with a decrease in visual acuity later. However, no attack was observed under the treatment with azathioprine. A complete treatment response was obtained in all of our patients diagnosed with isolated ON and MS. A doxy- cycline, rifampicin, and acetazolamide treatment was applied to our neurobrucellosis patient for 6 months. Interferon 1a [Rebif $\circledast$ (Merck comp.)] was administered to two MS patients who developed attacks in the follow-up (Table 2).

Patients were followed up for $2.65 \pm 2$ years. Two of the patients diagnosed with MS had no attacks in their follow-up to 2.5 years. Two other patients with MS had two (blurring vision) and three attacks (headache and blurring vision), respectively. Interferon 1a [Rebif® (Merck comp.)] was administered to the patients who experienced attacks. An attack presenting with blurring vision was experienced in the 1-year follow-up of the patient with NMO, and it was concluded with a cure. In the other patient with $\mathrm{NMO}$, total visual loss was present in the affected eyes. The patient with neurobrucellosis had no problems during the follow-up. The patient who with NMO had nearly complete loss of vision and a gait disorder during the 4.5-year follow-up (Table 2). The $13^{\text {th }}$ patient (Table 2) presented with a second attack months after the first attack of ON. OCB positivity was seen at the first and second attack. The second episode was accompanied by plaques in T2 and T1W images and contrast enhancement was also noticed.

\section{DISCUSSION}

The average age was $12.8 \pm 3.07$ years, and F/M ratio was 2.25 in our study. Wileyto et al. had found the average age as 12.2 year, and F/M ratio as 1.6 in their study (8). ON was $53.85 \%$ unilateral and $46.15 \%$ bilateral in our study. Wileyto et al. had determined similar rates of $58 \%$ unilateral and $42 \%$ bilateral (8). In our study, one patient of nine had received VEP, and all had various rates of abnormalities. In the study of Wileyto et al. there was $88 \%$ distortion in VEP (8). NMO is a demyelinating disease with high mortality and morbidity that starts with ON. Lately, the positivity of antibodies developed against the aquaporin 4 molecule have gained a supporting feature for the diagnosis of $\operatorname{NMO}(9,10)$. In our series, two patients who received NMO diagnosis also applied to the ON clinic. Frequent attacks were experienced in the follow-up of the patients and caused morbidity.

The incidence of MS was reported to be increased in patients with bilateral ON and OCB positive ones, and accordingly, abnormal MRI possibility is higher in patients with bilateral involvement (11). Also in our study, 3 (60\%) of the 5 patients diagnosed with MS had bilateral involvement, and all of them were OCB positive. MS was reported in $38 \%$ of the patients who applied with isolated ON (5). This rate was found as $36.36 \%$ in our study, and it was in compliance with the literature.

OCB are clonally restricted immunoglobulins which are produced by cerebrospinal fluid and parenchymal B lymphocytes. OCB are detected by isoelectric focus $(12,13)$. 
This is an important feature of ongoing inflammatory process in the central nervous system (CNS) and have been reported in a number of neuroinflammatory conditions (paraneoplastic syndromes, NMO spectrum disorders etc.) and infections (herpesvirus encephalitis etc.) (14). The potential role of OCB in maintaining immune responses and creating a neurodegenerative environment in MS has been increasingly noted (15). Some of the novel studies show the presence of $\mathrm{OCB}$ at the onset of MS; a higher level of gray matter pathology, increased severe disability, and cognitive impairment were compared to OCB-negative MS over a ten-year study period (16). In primary progressive MS, a lower incidence of OCB positivity has been reported than in relapsing-remitting MS. However, primary progressive MS has higher CSF immunoglobulin levels (17). Patients whose tests were positive for anti-myelin oligodendrocyte glycoprotein antibody (anti-MOG-Ab) had good responses to steroids in our study. In addition, OCB positivity is a weak prognostic indicator in this study.

In the treatment of acute $\mathrm{ON}$, pulse steroids are recommended for $3-5$ days in $20-30 \mathrm{mg} / \mathrm{kg} /$ day doses, and oral steroids for 4-6 weeks as maintenance. Most of the ON patients responded to this treatment. In our study, a complete response was not obtained in 9 patients, demyelination in 10 patients, and only the patient diagnosed with $\mathrm{NMO}$ developed morbidity. It is known that steroid treatment is generally positive in patients who have developed MS; however, it does not change the recurrence (5). In our series, a complete response was obtained in all of the four MS patients, and two patients developed recurrence in the follow-up.

The fact that our study is a retrospective study and contains a low number of patients may be assumed as negative aspects of our study. The absence of losses in patient data and the average follow-up time of 2.65 years may be assumed as positive aspects of our study.

\section{CONCLUSION}

ON should absolutely be considered in every child with blurred vision and vision loss. It may either be $\mathrm{ON}$, or it could be the precursor of a serious demyelinating disease. For this reason, patients should receive a meticulous neurological and visual examination. VEP, cranial imaging, and lumber puncture (if required) should be performed. Anti-MOG and OCB positivity are important in terms of prognosis.

Ethics Committee Approval: This study was approved by the Ethical Committee of the Inönü University Faculty of Medicine (Date: 2018, No: 10).

Informed Consent: Written consent was obtained from the participants.
Peer Review: Externally peer-reviewed.

Author Contributions: Conception/Design of Study- M.A.; Data Acquisition- M.A., S.K.; Drafting Manuscript- M.A., S.K.; Critical Revision of Manuscript- S.G.; Final Approval and AccountabilityM.A., S.K., S.G.

Conflict of Interest: Authors declared no conflict of interest.

Financial Disclosure: Authors declared no financial support.

Etik Komite Onayı: Bu çalışma için etik komite onayı İnönü Üniversitesi Tıp Fakültesi Etik Kurulu'ndan alınmıştır (Tarih: 2018, No: 10-18).

Bilgilendirilmiş Onam: Katılımcılardan bilgilendirilmiş onam alınmıştır.

Hakem Değerlendirmesi: Dış bağımsız.

Yazar Katkıları: Çalışma Konsepti/Tasarım- M.A.; Veri ToplamaM.A., S.K.; Yazı Taslağı- M.A., S.K.; iç̧eriğin Eleştirel İncelemesiS.G.; Son Onay ve Sorumluluk- M.A., S.K., S.G.

Çıkar Çatışması: Yazarlar çıkar çatışması beyan etmemişlerdir.

Finansal Destek: Yazarlar finansal destek beyan etmemişlerdir.

\section{REFERENCES}

1. Optic Neuritis Study Group. The 5-year risk of MS after optic neuritis. Experience of the optic neuritis treatment trial. Neurology 1997;49(5):1404-13. [CrossRef]

2. El-Dairi MA, Ghasia F, Bhatti MT: Pediatric optic neuritis. Int Ophthalmol Clin 2012;52(3):29-49. [CrossRef]

3. O'Riordan JI, Thompson AJ, Kingsley DP, et al. The prognostic value of brain MRI in clinically isolated syndromes of the CNS. A 10-year followup. Brain 1998;121(Pt 3):495-503. [CrossRef]

4. Banwell B, Kennedy J, Sadovnick D, et al. Incidence of acquired demyelination of the CNS in Canadian children. Neurology 2009;72(3):232-9. [CrossRef]

5. Melinda Y. Chang, MD, and Stacy L. Pineles, MD. Pediatric Optic Neuritis. Pediatric Neurology 2017;24(2):122-8. [CrossRef]

6. Cleary PA, Beck RW, Anderson MM, Jr, Kenny DJ, Backlund JY, Gilbert PR. Design, methods and conduct of the ONTT. Control Clin Trials 1993;14(2):123-42. [CrossRef]

7. Borchert M, Liu GT, Pineles S, Waldman AT. Pediatric Optic Neuritis: What Is New. J Neuroophthalmol 2017;37(Suppl 1):S14-S22. [CrossRef]

8. Wilejto M, Shroff M, Buncic JR, Kennedy J, Goia C, et al. The clinical features, MRI findings, and outcome of optic neuritis in children. Neurology 2006;67(2):258-62. [CrossRef]

9. Wingerchuk DM, Weinshenker BG. Neuromyelitis optica: clinical predictors of a relapsing course and survival. Neurology 2003;60(5):848-53. [CrossRef]

10. Lennon VA, Kryzer TJ, Pittock SJ, Verkman AS, Hinson SR. IgG marker of optic-spinal multiple sclerosis binds to the aquaporin-4 water channel. J Exp Med 2005;202(4):473-7. [CrossRef]

11. Morales DS, Siatkowski RM, Howard CW, Warman R. Optic neuritis in children. J Pediatr Ophthalmol Strabismus 2000;37(5):254-9. 
12. Freedman MS, Thompson EJ, Deisenhammer $F$, Giovannoni G, Grimsley G, Keir G, et al. Recommended standard of cerebrospinal fluid analysis in the diagnosis of multiple sclerosis: a consensus statement. Arch Neurol 2005;62(6):865-70. [CrossRef]

13. Obermeier B, Lovato L, Mentele R, Brück W, Forne I, Imhof A, et al. Related B cell clones that populate the CSF and CNS of patients with multiple sclerosis produce CSF immunoglobulin. J Neuroimmunol 2011;233(1-2):245-8. [CrossRef]

14. Juryńczyk M, Craner M, Palace J. Overlapping CNS inflammatory diseases: differentiating features of $\mathrm{NMO}$ and MS. J Neurol Neurosurg. Psychiatry 2015;86(1):20-5. [CrossRef]
15. Pryce G, Baker D. Oligoclonal bands in multiple sclerosis; Functional significance and therapeutic implications. Does the specificity matter? Mult Scler Relat Disord 2018;25(20):131-7. [CrossRef]

16. Farina G, Magliozzi R, Pitteri M, Reynolds R, Rossi S, Gajofatto $A$, et al. Increased cortical lesion load and intrathecal inflammation is associated with oligoclonal bands in multipl esclerosis patients: a combined CSF and MRI study. J Neuroinflamm 2017;14(1):40. [CrossRef]

17. Lourenco P, Shirani A, Saeedi J, Oger J, Schreiber WE, Tremlett H. Oligoclonal bands and cerebrospinal fluid markers in multiple sclerosis: associations with disease course and progression. Mult Scler 2013;19(5),577-84. [CrossRef] 